\title{
Substrate specificity of the periplasmic dipeptide-binding protein from Escherichia coli: experimental basis for the design of peptide prodrugs
}

\author{
Mark W. Smith, † David R. Tyreman, † Gillian M. Payne, \\ Neil J. Marshall and John W. Payne
}

Author for correspondence: John W. Payne. Tel: +44 1248 382349. Fax: +44 1248370731. e-mail: j.w.payne@bangor.ac.uk

School of Biological Sciences, University of Wales, Bangor LL57 2UW, UK

\begin{abstract}
Pure dipeptide-binding protein (DppA) from Escherichia coli was studied in a filter binding assay to determine its binding specificity. A substrate:DppA stoichiometry of $1: 1$ was found with both $\left[{ }^{14} \mathrm{C}\right] \mathrm{AlaAla}$ and $\mathrm{Ala}\left[{ }^{14} \mathrm{C}\right] \mathrm{Phe}$. Surprisingly, substrate binding did not vary over the pH range pH 3-9.5. Different dipeptides yielded liganded protein with various pl values, implying that DppA can undergo subtly different conformational changes to accommodate different substrates. Using [125I]Tyr-peptides as substrates in competition assays, the relative binding affinities for a range of dipeptides were found to parallel their overall transport rates into $E$. coli through the dipeptide permease (Dpp), showing that DppA alone controls the specificity of Dpp. With a series of substituted glycyl peptides, binding affinity was progressively enhanced by alkylation (with methyl to butyl) of the $\mathrm{N}$-terminal $\alpha$-amino group. Thus, results from this approach provide an essential experimental basis, which complements the information from the crystal structure of DppA, for the design of peptidomimetic antibacterials targeted for transport through Dpp.
\end{abstract}

Keywords: Escherichia coli, dipeptide transport, peptide prodrugs, periplasmic binding protein, antibacterial peptides

\section{INTRODUCTION}

In both prokaryotic and eukaryotic organisms, peptides perform an important nutritional role (Matthews \& Payne, 1980; Payne \& Smith, 1994). Systems to transport peptides occur in many species and generally function to accumulate intact peptides intracellularly, where they are hydrolysed. This mechanism confers many advantages (Payne, 1980), being energetically more favourable than one of extracellular peptide cleavage followed by uptake of constituent amino acids; and, by avoiding competition between individual residues, it also allows a more balanced uptake of amino acids.

Peptide transport by bacteria has been most studied in the Gram-negative bacteria Escherichia coli and

† Present address: Cortecs plc, Newtech Square, Deeside Industrial Park, Flintshire CH5 2NT, UK.

Abbreviations: Dpp, dipeptide permease; Opp, oligopeptide permease; RPC, reverse-phase chromatography; TFA, trifluoroacetic acid; Tpp, tripeptide permease.
Salmonella typhimurium. These species possess three genetically distinct peptide permeases with overlapping substrate specificities: the oligopeptide, tripeptide and dipeptide permeases (Payne \& Smith, 1994). The oligopeptide permease (Opp) is the main peptide-transport system and functions in the utilization of peptide substrates containing up to about six amino acid residues. Opp is encoded by five genes, oppABCDF (Hiles et al., 1987), and is a member of the periplasmicbinding-protein-dependent family of traffic ATPases (Ames et al., 1990). The crystal structure of the binding protein, OppA, has been reported (Tame et al., 1994, 1995). Uptake via this system requires a peptide to have a positively charged $\mathrm{N}$-terminal $\alpha$-amino group (Payne, $1974,1980)$, but there is less specificity towards the Cterminal $\alpha$-carboxyl group, which may be absent or derivatized (Payne \& Gilvarg, 1968; Atherton et al., 1983; Hammond et al., 1987; Morley et al., 1983). All natural amino acid side chains and various derivatized ones are accepted by OppA (Alves \& Payne, 1980; Perry \& Gilvarg, 1984), although for recycling of peptido- 
glycan-derived peptides by Opp (Goodell \& Higgins, 1987) a separate binding protein, MppA, is required (Park et al., 1998).

The tripeptide permease (Tpp) is poorly characterized biochemically, although it has been cloned from $S$. typhimurium (Gibson et al., 1984). It favours tripeptide substrates containing hydrophobic residues, whilst also showing activity towards dipeptides (Alves \& Payne, 1980). It is not a traffic ATPase but belongs to the class of transporters that have only a single membrane protein in which transport is energized by a proton-motive force (Smith, 1992; J. W. Payne, unpublished results).

The dipeptide permease (Dpp) has, as its name implies, a preference for dipeptide substrates, but it can also transport tripeptides to a lesser extent (Alves \& Payne, 1980; Payne \& Smith, 1994). Evidence that Dpp is a traffic ATPase came from identification of a periplasmic dipeptide-binding protein (DppA) (Abouhamad et al., 1991; Olson et al., 1991), and subsequently from sequencing the $d p p$ locus in E. coli, which comprises an operon of five genes (Abouhamad \& Manson, 1994). Dpp has also been implicated in dipeptide chemotaxis (Manson et al., 1986). The crystal structure of DppA has been reported (Nickitenko et al., 1995; Dunten \& Mowbray, 1995). Overall, Dpp has a broad substrate specificity analogous to Opp but it is less tolerant than Opp of side-chain modification (Perry \& Gilvarg, 1984) and has a stricter requirement for a free C-terminal $\alpha$ carboxyl group.

Characterization of peptide transporters in other organisms, e.g. plants, and mammalian intestine and kidney, indicates that systems analogous to those above occur universally and possess similar specificities (Taylor \& Amidon, 1995; Grimble \& Backwell, 1998). This observation is entirely reasonable considering that the substrates for all these transporters comprise essentially the same pool of peptides derived from protein hydrolysis.

It has been recognized for some time that the unusually broad substrate specificities of peptide transporters make them particularly attractive targets to exploit for delivery of therapeutic agents. The utility of this approach has been endorsed by the finding that a range of such compounds occur naturally. Various microorganisms produce peptide analogues, e.g. bacilysin, bialaphos, lindenbein, that show antimicrobial or phytopathogenic activity, which is dependent upon the compounds entering a cell via peptide transporters (Payne \& Smith, 1994). Bioactive peptide compounds that subvert peptide transporters in this way are referred to as smugglins (Tyreman et al., 1998). Many attempts have been made to design such compounds based upon the limited information available on the structural specificities of the transport systems (Taylor \& Amidon, 1995; Grimble \& Backwell, 1998; Payne 1995; Tyreman et al., 1992, 1998). To be able to design effective smugglins it is essential to have good information about the recognition specificity of the transporters, and the work described here addresses this feature.
As part of an approach to exploit the widely distributed Dpp for the delivery of normally impermeant antibacterial agents, we report here the purification of DppA from E. coli and characterization of its substrate-binding properties. The findings are related to the overall transport characteristics of the permease. Substrate binding is shown to cause several different conformational changes in the binding protein. These results contribute to the fundamental information needed for evaluating the structural basis for molecular recognition by DppA, and for the rational design of peptide carrier prodrugs able to be transported by Dpp (Payne, 1986, 1995; Smith \& Payne, 1990; Tyreman et al., 1992, 1998). Preliminary accounts of certain aspects of the results have been reported previously (Tyreman et al., 1998).

\section{METHODS}

Bacterial strains and growth conditions. Escherichia coli K-12 strain Morse2034 trpE9851 leu $277 \mathrm{~F}^{-} \mathrm{IN}(r r n D-r r n E)$ (Morse \& Guertin, 1972) was used as the parental strain from which peptide-transport mutants were derived. Bacteria were grown at $37^{\circ} \mathrm{C}$ with rotary shaking in minimal A medium (Davis \& Mingioli, 1950), normally supplemented with $0.5 \mathrm{mM} \mathrm{Leu,}$ $0.2 \mathrm{mM}$ Trp and $0.4 \%(\mathrm{w} / \mathrm{v})$ glucose. Spontaneous mutants with a deletion extending from ton $B$ to $t d k$, which includes the Opp operon, were obtained by first selecting for colonies resistant to triornithine (Payne \& Gilvarg, 1968) on minimal A plates supplemented with $0.5 \mathrm{mM}$ Leu, $0.2 \mathrm{mM} \operatorname{Trp}, 0.25 \mathrm{mM}$ triornithine and $0.05 \mathrm{mM}$ ferric chloride. Triornithine-resistant mutants, characterized as oligopeptide transport defective, were screened for the ton $B$ phenotype by their resistance to bacteriophage $\phi 80_{\mathrm{vir}}$, and, more conveniently, also using their sensitivity to low levels of iron by their failure to grow on LB plates containing $0.2 \mathrm{mM}$ of the iron-chelating compound 2,2'-dipyridyl, and secondly for deoxythymidine kinase deficiency, $t d k$, by inability to grow on plates containing fluorouracil (Igarashi et al., 1967). One such Opp deletion mutant, PA0183, was then used to obtain mutants defective in Dpp. Resistant colonies were selected on minimal A medium plates containing either Lys-aminoxyAla (Payne et al., 1984) or ProVal, supplemented with $0 \cdot 2 \mathrm{mM}$ Trp and 0.5 mM LeuLeuLeu.

Mutants defective in Dpp were selected from PA0183 by resistance to a particular inhibitory dipeptide (LysaminoxyAla or ProVal) coupled with cross-resistance to various toxic peptides (see Results) as described earlier (Smith \& Payne, 1990). From amongst these strains, mutants deficient in DppA were characterized by SDS-PAGE analysis of osmotic shock fluids.

Mutants defective in Tpp were selected from PA0183 by resistance to ValValVal coupled with cross-resistance to alafosfalin as described earlier (Smith \& Payne, 1990). One such mutant, strain PA0410, was used for measurements of transport by Dpp (see Results).

Osmotic shock. This was performed by a modification of the procedure of Berger \& Heppel (1972). Bacteria were grown to late-exponential phase, harvested by centrifugation at $8000 \mathrm{~g}$ and washed twice with $10 \mathrm{mM}$ Tris/ $\mathrm{HCl}, \mathrm{pH} 7 \cdot 3,30 \mathrm{mM}$ $\mathrm{NaCl}$ at room temperature. The cell pellet was resuspended at room temperature in $20 \%$ (w/v) sucrose, $33 \mathrm{mM}$ Tris $/ \mathrm{HCl}$, pH 7·3, $1 \mathrm{mM}$ EDTA, using $32 \mathrm{ml}$ per litre of original cell culture. After gentle shaking for $5 \mathrm{~min}$, the cells were pelleted by centrifugation and then rapidly resuspended in an equi- 
valent volume of ice-cold distilled water. The suspension was kept on ice for $3 \mathrm{~min}$, then $\mathrm{MgCl}_{2}$ was added to $1 \mathrm{mM}$ and the suspension left standing for a further $10 \mathrm{~min}$. The suspension was centrifuged at $8000 \mathrm{~g}$ for $10 \mathrm{~min}$, and the supernatant solution was filtered through a sterile $0.45 \mu \mathrm{m}$ cellulose acetate filter. The filtrate was concentrated about 50 -fold, to a protein concentration of $5-10 \mathrm{mg} \mathrm{ml} \mathrm{m}^{-1}$, using an Amicon ultrafiltration cell. The concentrated osmotic shock fluid was dialysed at $4{ }^{\circ} \mathrm{C}$ against $50 \mathrm{mM}$ malonic acid/ $\mathrm{NaOH}$ buffer, $\mathrm{pH} 4 \cdot 8$, centrifuged for $5 \mathrm{~min}$ at $12000 \mathrm{~g}$ and the supernatant solution used in further studies.

Purification of dipeptide-binding protein. The osmotic shock fluid from E. coli Morse2034 was used as the source of DppA. Samples of concentrated osmotic shock fluid, containing about $12 \mathrm{mg}$ protein, were applied to an FPLC MonoS HR5/5 cation-exchange column, pre-equilibrated with $50 \mathrm{mM}$ malonate/ $\mathrm{NaOH}$ buffer $\mathrm{pH} 4 \cdot 8$, at a flow rate of $1.5 \mathrm{ml} \mathrm{min}^{-1}$. Desorption of bound protein was effected with a linear gradient of $\mathrm{NaCl}(0-1 \mathrm{M})$. Fractions containing DppA, as determined by SDS-PAGE and peptide-binding activity (see below), were pooled (about $2.5 \mathrm{ml}$ ), and aliquots (about $1 \mathrm{ml}$ ) were injected onto an FPLC fast desalting HR10/10 column, which had been pre-equilibrated with $20 \mathrm{mM}$ Tris/ $\mathrm{HCl}, \mathrm{pH}$ 7.8; DppA eluted in the void volume.

Samples of the DppA fractions, containing about $1 \mathrm{mg}$ protein, were applied to an FPLC MonoQ HR5/5 anion-exchange column, pre-equilibrated with $20 \mathrm{mM}$ Tris/ $\mathrm{HCl}, \mathrm{pH} 7 \cdot 8$, at a flow rate of $1.5 \mathrm{ml} \mathrm{min}^{-1}$. Desorption and detection of DppA were accomplished as described for the MonoS column. Fractions containing DppA were pooled (about $3 \mathrm{ml}$ ) and aliquots (about $1 \mathrm{ml}$ ) were passed through an FPLC fast desalting HR10/10 column, which had been pre-equilibrated with $5 \mathrm{mM}$ ammonium bicarbonate. The purified DppA was lyophilized and stored at $-20^{\circ} \mathrm{C}$.

Reverse-phase chromatography (RPC) was also carried out on occasion to remove any bound ligand from the purified DppA. Lyophilized DppA (about $100 \mu \mathrm{g}$ ) was dissolved in $0.1 \%(\mathrm{v} / \mathrm{v})$ aqueous trifluoroacetic acid (TFA) $(100-500 \mu \mathrm{l})$, and the sample applied at a flow rate of $0.5 \mathrm{ml} \mathrm{min} \mathrm{m}^{-1}$ onto an FPLC Pro-RPC HR5/10 column pre-equilibrated with aqueous $0 \cdot 1 \%(\mathrm{v} / \mathrm{v})$ TFA. Bound DppA was eluted using an increasing linear gradient of acetonitrile $(0-100 \%, \mathrm{v} / \mathrm{v})$ with aqueous TFA $(0 \cdot 1 \%, w / v)$. Fractions containing DppA were pooled (about $2 \mathrm{ml}$ ), lyophilized and stored at $-20^{\circ} \mathrm{C}$.

$\mathrm{N}$-Terminal protein sequencing. A purified sample of DppA was subjected to automated Edman degradation using an Applied Biosystems model 470A gas-phase sequencer.

SDSPAGE. Samples were prepared for electrophoresis in a solution of $0.2 \mathrm{M}$ Tris $/ \mathrm{HCl}, \mathrm{pH} 6.8,2 \%$ (w/v) SDS, $10 \%$ $(\mathrm{w} / \mathrm{v})$ sucrose, $0.01 \%(\mathrm{w} / \mathrm{v})$ bromophenol blue and $5 \%(\mathrm{v} / \mathrm{v})$ $\beta$-mercaptoethanol. Samples were either boiled for $2 \mathrm{~min}$, or incubated at $37^{\circ} \mathrm{C}$ for $2 \mathrm{~h}$ prior to running on $13 \%$ (acrylamide: bisacrylamide ratio $37 \cdot 5: 1$ ) slab gels (18 cm $\times 12 \mathrm{~cm} \times 1 \mathrm{~mm}$ thick) as described by Laemmli (1970). Sigma $6 \mathrm{H}$ molecular mass calibration markers were used. Gels were stained with $0.5 \%(\mathrm{w} / \mathrm{v})$ Kenacid $\mathrm{R}$ in $7 \%(\mathrm{v} / \mathrm{v})$ acetic acid, $50 \%(\mathrm{v} / \mathrm{v})$ methanol, and destained with $7 \%(\mathrm{v} / \mathrm{v})$ acetic acid, $50 \%(\mathrm{v} / \mathrm{v})$ methanol, or were silver stained according to the procedure of Heukeshoven \& Dernick (1988). Laser densitometric scanning of protein gels was carried out using a model 2202 Ultrascan Laser Densitometer (LKB), at a wavelength of $633 \mathrm{~nm}$.

Isoelectric focussing (IEF). Protein samples, $(0 \cdot 1 \mathrm{nmol} ; 25 \mu \mathrm{M}$ final concentration) were prepared in distilled water and incubated with or without peptide (see Results) for $1 \mathrm{~h}$ at $37^{\circ} \mathrm{C}$ prior to their application to Pharmacia IEF Phast Gels, with a $\mathrm{pH}$ range of either 3-9 or 5-8. Electrophoresis was carried out on a Pharmacia PhastSystem according to the Pharmacia manual. After electrophoresis, proteins were fixed with $20 \%(\mathrm{w} / \mathrm{v})$ trichloroacetic acid for $20 \mathrm{~min}$ at $20^{\circ} \mathrm{C}$, washed with a solution of $10 \%(\mathrm{v} / \mathrm{v})$ acetic acid and $30 \%$ $(\mathrm{v} / \mathrm{v})$ methanol for $2 \mathrm{~h}$ at $20{ }^{\circ} \mathrm{C}$, stained with $0.02 \%(\mathrm{w} / \mathrm{v})$ Phast Gel Blue R, $0 \cdot 1 \%$ (w/v) copper sulphate, $10 \%$ (v/v) acetic acid, $30 \%(\mathrm{v} / \mathrm{v})$ methanol and destained with $10 \%$ (v/v) acetic acid, 30\% (v/v) methanol. Gels to be silver stained were washed twice with $10 \%$ (v/v) ethanol (5 min per wash) after fixation, and then stained according to the method of Heukeshoven \& Dernick (1988), starting with the distilled water washes.

Synthesis and purification of ${ }^{\mathbf{1 2 5}} \mathrm{I}$-labelled tyrosine peptides. These were prepared as described elsewhere (Tyreman et al., 1992).

Peptide-binding activity in column fractions. This procedure was adapted from that described by Richarme \& Kepes (1983). Lyophilized samples of fractions from column chromatography (see Results for details), were dissolved in $100 \mu \mathrm{l} 10 \mathrm{mM}$ HEPES/ $\mathrm{NaOH}$ buffer $\mathrm{pH} 7 \cdot 3$ and either $1 \mathrm{nmol}$ Gly $\left[{ }^{125} \mathrm{I}\right] \mathrm{Tyr}(10 \mu \mathrm{l}, 1 \cdot 8 \mathrm{kBq})$ or $1 \mathrm{nmol}\left[{ }^{125} \mathrm{I}_{2}\right]$ TyrGlyGly $(10 \mu \mathrm{l}$, $2.5 \mathrm{kBq}$ ) in distilled water was added. The samples were incubated at $37^{\circ} \mathrm{C}$ for $10 \mathrm{~min}$, then $900 \mu \mathrm{l}$ of saturated ammonium sulphate at $4{ }^{\circ} \mathrm{C}$ was added; the solution was mixed and then quickly filtered under vacuum (about $600 \mathrm{mmHg})$ through nitrocellulose filters $(0 \cdot 2 \mu \mathrm{m})$, pre-wetted with distilled water. The filters were washed three times with $2 \mathrm{ml}$ aliquots of saturated ammonium sulphate and then measured for gamma radioactivity. Controls for non-specific binding of radioactivity were performed in which the protein was omitted from the mixture.

Assay for peptide binding to the dipeptide-binding protein. This was a modification of that described above for column fractions. Lyophilized DppA was dissolved in $10 \mathrm{mM}$ HEPES/ $\mathrm{NaOH}$ buffer $\mathrm{pH} 7 \cdot 3$ and preincubated for $30 \mathrm{~min}$ at $37^{\circ} \mathrm{C}$. To $50 \mu \mathrm{l}$ samples, containing $0.66 \mathrm{nmol} \mathrm{DppA}$, a $10 \mu \mathrm{l}$ solution containing $0.4 \mathrm{nmol}$ Gly $\left[{ }^{125} \mathrm{I}\right] \mathrm{Tyr}(840 \mathrm{~Bq})$ plus competing peptide substrate (see Results) in the same buffer was added. After incubation for $10 \mathrm{~min}$ at $37^{\circ} \mathrm{C}$, saturated ammonium sulphate $(900 \mu \mathrm{l})$ at $4{ }^{\circ} \mathrm{C}$ was added, and the samples were treated as described above, except that $0.2 \mu \mathrm{m}$ polycarbonate filters were used. Controls were performed in which either DppA or competing peptide was omitted.

The $\mathrm{pH}$ dependence of peptide binding by DppA, purified by ion-exchange chromatography, was measured using the above filter binding assay, in duplicate, using $5 \mu \mathrm{M}(0.3 \mathrm{nmol}) \mathrm{DppA}$ and $250 \mu \mathrm{M}(15 \mathrm{nmol})$ Ala[ $\left.\mathrm{U}_{-}{ }^{14} \mathrm{C}\right] \mathrm{Ala}\left(11 \cdot 4 \mathrm{MBq} \mathrm{mmol}^{-1}\right)$. Assays were carried out in a total volume of $60 \mu \mathrm{l}$ using the following buffers: $10 \mathrm{mM}$ malonic acid/ $\mathrm{NaOH} \mathrm{pH} 3,5,6$; $10 \mathrm{mM}$ Bistris propane/ $\mathrm{HCl} \mathrm{pH} \mathrm{6 \cdot 5,} \mathrm{7 \cdot 5,} 8 \cdot 5$ and 9.5. A control, lacking protein, was performed at each $\mathrm{pH}$.

Fluorescence emission spectroscopy. This technique was based upon earlier reports of the conformational changes associated with ligand binding by OppA (Guyer et al., 1986) and DppA (Blank, 1987). Lyophilized DppA was dissolved in $10 \mathrm{mM}$ HEPES/ $\mathrm{NaOH}$ buffer $\mathrm{pH} 7 \cdot 3$ to a concentration of $1 \mu \mathrm{M}$. After incubation for $1 \mathrm{~h}$ at room temperature, the fluorescence emission spectrum was measured between 300 and $385 \mathrm{~nm}$ using excitation at $290 \mathrm{~nm}$. A sample $(2 \mu \mathrm{l})$ of an aqueous solution of a peptide substrate (see Results) was added to the protein in a cuvette to give a concentration of 
$10 \mu \mathrm{M}$. After mixing, the solution was incubated at room temperature for $2 \mathrm{~min}$, before remeasurement of the fluorescence emission spectrum. Controls consisted of $10 \mu \mathrm{M}$ solutions of peptide in buffer.

Measurement of peptide transport. This was carried out using fluorescence labelling techniques with dansyl chloride or fluorescamine, or using radioactively labelled peptide, as described previously (Payne \& Nisbet, 1980).

\section{RESULTS}

\section{Purification of the dipeptide-binding protein}

Two complementary approaches were taken to identify the dipeptide-binding protein in osmotic shock fluids from E. coli. Firstly, mutants selected as being defective in dipeptide transport were screened for loss of a periplasmic protein and, secondly, after column chromatography of osmotic shock fluids, fractions were assayed for ability to bind dipeptides.

Dpp mutants $(d p p)$ were isolated from E. coli strain PA0183, which carried a deletion for Opp. To obtain strain PA0183, over 600 independent mutants selected as spontaneously resistant to triornithine were screened for failure to grow on iron-limited medium, indicative of a defect in tonB (Pugsley \& Reeves, 1976). The selective medium was produced by incorporation of the chelating agent $2,2^{\prime}$-dipyridyl. Six tonB mutants were obtained, four of which characteristically gave small, intensely red colonies when streaked onto MacConkey medium with galactose, whereas two gave white streaks, indicating that their deletions extended into galU. The deletions were all found to extend beyond opp in the opposite direction by showing that the colonies were also $t d k$, indicated by their failure to grow on plates containing uridine and thymidine supplemented with fluorouracil (Igarashi et al., 1967). Their deficiency in Opp was confirmed by their cross-resistance to various toxic tripeptides including ProAla-aminoxyAla (Payne et al., 1984; Smith \& Payne, 1990), failure to utilize ProLeuGly amide as a source of leucine and absence of the oligopeptide-binding protein from osmotic shock fluids. One of the four $\Delta(t o n B-t d k)$ opp mutants was designated PA0183.

Use of strain PA0183 facilitates the isolation of $d p p$ mutants, for dipeptides can also be transported extensively through Opp. Spontaneous $d p p$ mutants were selected (see Methods) as resistant to either the toxic dipeptide Lys-aminoxyAla (Payne et al., 1984) or to ProVal (as a source of valine, which is inhibitory to strains of valine-sensitive E. coli $\mathrm{K}-12$ ) in media containing trileucine to satisfy the auxotrophic requirement for leucine. Use of this tripeptide ensured against selection of mutants in Tpp, for in PA0183 only Tpp provides a route by which trileucine can be transported effectively. Each putative $d p p$ mutant was checked for cross-resistance against the other toxic dipeptide, and for loss of ability to utilize LeuTrp as a source of its required amino acids; continued sensitivity to trivaline and to alafosfalin confirmed Tpp to be unchanged (Smith \& Payne, 1990). Twenty-nine mutants possessing

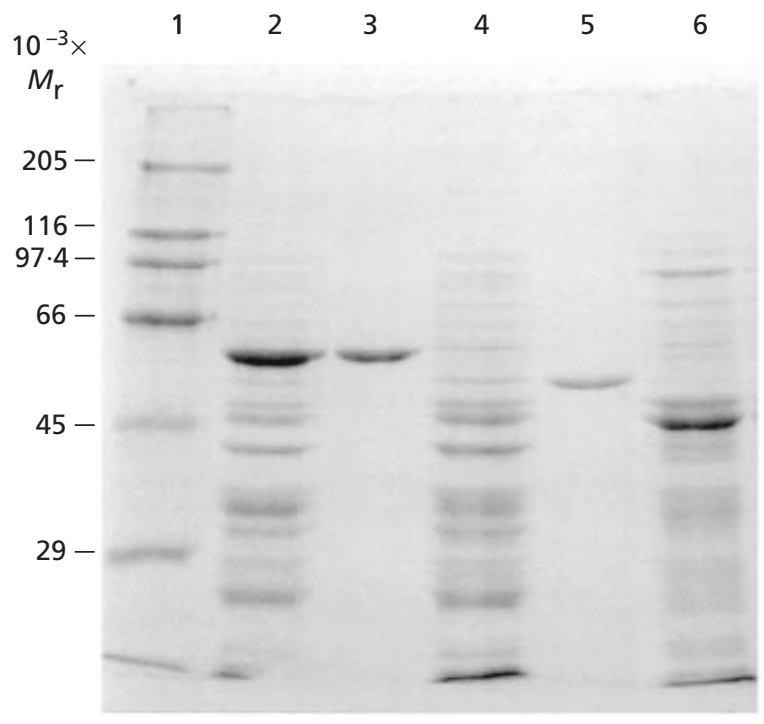

Fig. 1. SDS-PAGE of osmotic shock fluids and peptide-binding proteins of $E$. coli. Tracks: 1, $M_{\mathrm{r}}$ markers; 2 , osmotic shock fluid from wild-type strain Morse2034; 3, purified sample of OppA; 4, osmotic shock fluid from mutant strain PA0183 $\Delta(o p p) ; 5$, purified sample of DppA; 6, osmotic shock fluid from mutant strain PA0333 $\Delta(o p p) d p p$.

a defective dipeptide-transport phenotype were osmotically shocked, and the released proteins were examined by SDS-PAGE. OppA $\left(M_{\mathrm{r}} 58000\right)$ was absent from the opp deletion mutant PA0183 and its derived $d p p$ strains (Fig. 1), whilst a main protein $\left(M_{\mathrm{r}} 56000\right)$ was missing from four of the $d p p$ mutants (PA0333, PA0334, PA0345 and PA0349), compatible with loss of the dipeptide-binding protein DppA (Fig. 1); these observations are similar to previous reports in which DppA- and OppA-defective mutants have been described (Abouhamad et al., 1991; Manson et al., 1986; Olson et al., 1991). The inferred frequency of mutations of the corresponding gene $d p p A$ is compatible with Dpp being encoded by an operon composed of several genes. However, when pure DppA became available (see below), polyclonal antibodies and several monoclonal antibodies were raised against it and used to examine by Western blotting the osmotic shock fluids from the above $d p p$ mutants (results not shown). This study showed that strains PA0333, PA0334 and PA0345 produced no DppA, whereas mutant PA0349 produced a very low level of a protein corresponding to DppA and a major cross-reacting protein species with an $M_{\mathrm{r}}$ about 7000 lower. The polyclonal antibody preparation also showed cross-reactivity towards OppA.

During development of the purification scheme for DppA, we sought to ensure that it could not be contaminated with OppA, for even a low percentage of contamination could confuse conclusions on its binding specificity. To this end, we monitored column fractions for binding activity towards radioactively labelled diand tripeptides. A sample of the concentrated, dialysed osmotic shock fluid (see Methods) was applied to a 


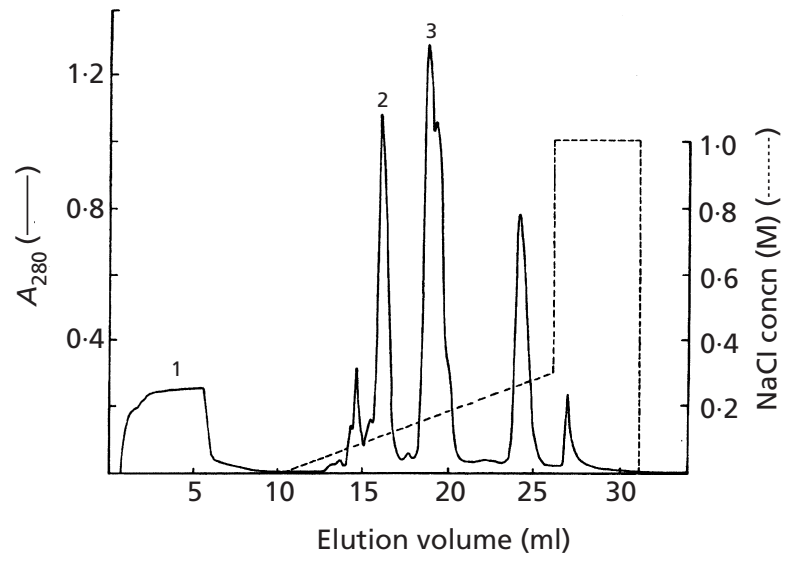

Fig. 2. Purification of DppA using FPLC with a MonoS column. Peaks labelled 2 and 3 contain DppA and OppA, respectively.

MonoS cation-exchange column, as shown in Fig. 2. The proteins that passed through the column and the protein fractions eluted by the applied salt gradient were assayed for binding activity using the ammoniumsulphate-dependent filter binding assay with Gly $\left[{ }^{125} \mathrm{I}\right] \mathrm{Tyr}$ and $\left[{ }^{125} \mathrm{I}_{2}\right]$ TyrGlyGly as substrates. A fraction eluting at $140 \mathrm{mM} \mathrm{NaCl}$ (Fig. 2, peak 2) uniquely bound the radioactive dipeptide. Other fractions gave zero activity. Thus, in a representative assay, using $1 \mathrm{nmol}$ protein with $1 \mathrm{nmol}$ Gly $\left[{ }^{125} \mathrm{I}\right] \mathrm{Tyr}$ (1.8 kBq, 110000 d.p.m.), $4270 \pm 300$ d.p.m. were bound, whereas with $1 \mathrm{nmol}\left[{ }^{125} \mathrm{I}_{2}\right]$ TyrGlyGly $(2 \cdot 5 \mathrm{kBq}$, 148000 d.p.m.) no radioactivity became bound. When $2 \mathrm{nmol}$ AlaAla was added as a competitor together with the above dipeptide, no radioactivity was bound, whereas 2 nmol D-Ala-D-Ala showed no competitive ability and the radioactive counts bound were unaffected. When a sample of this fraction was examined by SDS-PAGE (results not shown), the main protein present corresponded to that identified as the putative dipeptide-binding protein from characterization of the $d p p$ mutants (Fig. 1). Laser densitometric scanning of this Kenacid R-stained gel indicated DppA to be about $80 \%$ pure. Importantly, failure of this fraction to bind $\left[{ }^{125} \mathrm{I}_{2}\right]$ TyrGlyGly and inspection of the SDS-PAGE gel both indicated that the fraction was not contaminated with OppA. This protein, with an $M_{\mathrm{r}}$ value of 58000 (Fig. 1), specifically bound the above radioactively labelled tripeptide and eluted as the main peak at $180 \mathrm{mM} \mathrm{NaCl}$ (Fig. 2, peak 3). Thus, these results indicated that it was not only feasible but actually quite convenient to obtain both DppA and OppA as part of the same purification scheme and, therefore, the wildtype strain Morse2034 was routinely used as a source of both binding proteins, rather than using the OppA deletion strain PA0183 to obtain DppA alone.

When the DppA fraction from the MonoS column was applied to a MonoQ anion-exchange column, DppA eluted as a sharp, but split peak at $110 \mathrm{mM} \mathrm{NaCl}$ (result not shown). The fraction containing OppA was purified in a similar manner, to yield a product that eluted at the same salt concentration. SDS-PAGE analysis of these MonoQ fractions showed each to yield a single, sharp band that was at least $98 \%$ pure as determined by laser densitometric scanning (result not shown). The yield of pure DppA was about $2 \mathrm{mg}$ from $25 \mathrm{mg}$ of osmotic shock proteins obtained from 51 of E. coli culture.

A sample of this purified DppA was subjected to automatic Edman degradation (see Methods) and the following unique amino acid sequence was determined for the first 33 residues of the mature protein: LysThrLeuValTyr(Cys)SerGluGlySerProGlyGlyPhe AsnProGlnLeuPheThrSerGlyThrThrTyrAspAlaSerSerValPro(Leu)Tyr. The two residues in parentheses were identified tentatively. This $\mathrm{N}$-terminal protein sequence matched exactly the N-terminus of the polypeptide encoded by the $d p p A$ gene from E. coli (Olson $e t$ al., 1991; Abouhamad et al., 1991); however, it differs from that reported for the DppA for which the crystal structure was determined by Nickitenko et al. (1995), in which Thr20 is changed to Ile.

\section{Dipeptide-binding protein can occur in different pl forms}

The protein sequencing and SDS-PAGE studies indicated that DppA purified as above was a single pure species; however, when a sample was examined by IEF it was found to comprise three main components, with pI values of $5.9,6.0$ and 6.1 (Fig. 3, track 11). Furthermore, when a sample was subjected to RPC using a Pro-RPC column (see Methods), it yielded a single sharp peak at $47 \%$ acetonitrile (result not shown), which ran as a single species on IEF with a pI value of $6 \cdot 1$ (Fig. 3, tracks 2 and 8). Using the isoelectric program in the Wisconsin GCG package available from the Daresbury Laboratories, the theoretical pI of DppA was calculated as 5.94. We interpret these results as indicating that the forms of $\mathrm{pI} 5.9$ and 6.0 represent protein with natural, bound ligands, which are removed by the low-pH and solvent treatment accompanying RPC to yield the ligand-free, native form of $\mathrm{pI} 6 \cdot 1$. Corroboration of this view came from incubation of the ionexchange-purified protein with synthetic dipeptides; e.g. with AlaPhe, the mixed pI forms of DppA were converted mainly to the conformer of pI $5 \cdot 9$ (Fig. 3, track 10). On the other hand, with RPC-purified protein, AlaAla caused a shift to the pI 6.0 form (Fig. 3, tracks 3-7) and AlaPhe mainly to the pI 5.9 form (Fig. 3, track 9). Similar treatment with Ala-D-Phe or D-Ala-D-Ala (which are not ligands) produced no change in the IEF profile (results not shown).

\section{Substrate-binding determined by fluorescence emission spectroscopy}

The changes in the pI of DppA, which occur upon binding of different substrates, are considered to arise from conformational changes in the protein. The IEF results imply that DppA can exist in at least three interconvertible conformations, which include two liganded forms. A series of experiments was therefore 

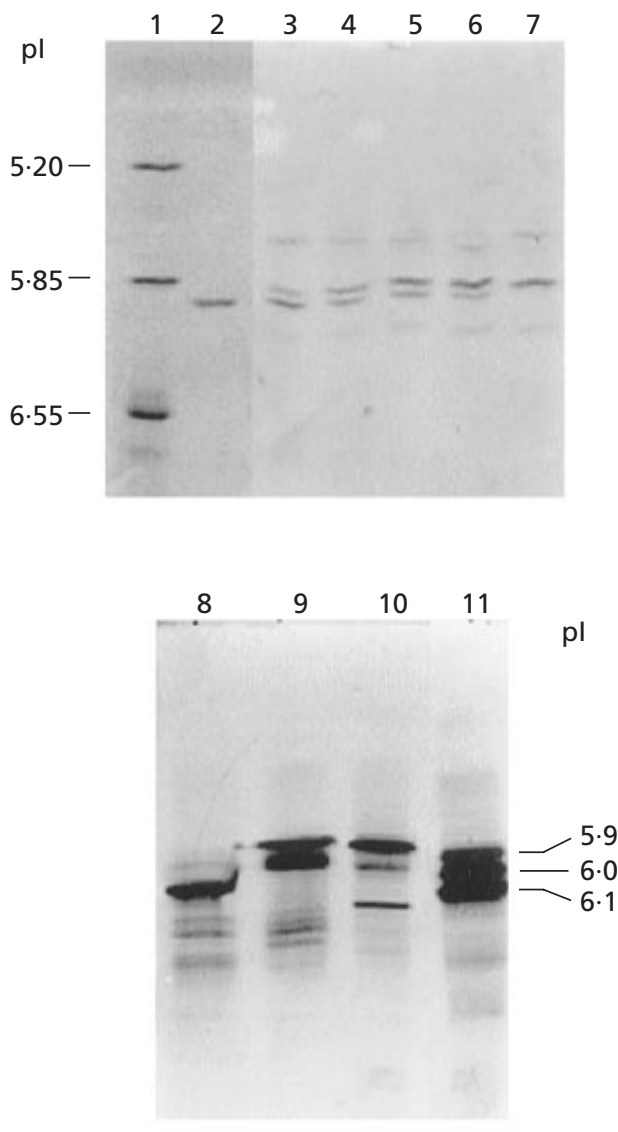

Fig. 3. IEF of DppA with and without added peptide ligands. Tracks: 1, pl markers; 2, DppA purified by ion-exchange on MonoS and MonoQ columns and RPC; 3-7, DppA purified as in 2 and incubated at molar ratios of DppA: AlaAla of $1: 0 \cdot 2,1: 0 \cdot 3$, $1: 0.4,1: 0.6$ and $1: 1$ in tracks $3,4,5,6$ and 7 , respectively; 8 , DppA purified by ion-exchange and RPC; 9 , DppA purified as in 8 incubated at a molar ratio of 1:10 with AlaPhe; 10, DppA purified by ion-exchange as in 11 and incubated at a molar ratio of 1:10 with AlaPhe; 11, DppA purified by ion-exchange alone. To demonstrate more clearly the presence of multiple DppA bands under certain conditions, protein samples used in tracks 8-11 were overloaded compared with those applied in tracks 2-7.

performed to determine whether these conformational changes could be observed in the fluorescence emission spectrum of the protein. DppA purified by ion-exchange chromatography exhibited fluorescence with an emission maximum at $330 \mathrm{~nm}$, when excited at $290 \mathrm{~nm}$ (Fig. 4). The addition of a 10 -fold molar excess of AlaAla caused fluorescence quenching $(-5 \cdot 9 \%$ at maximum wavelength) and a shift of the wavelength maximum to $329 \mathrm{~nm}$ (Fig. 4a). This change occurred over a 3 min incubation and was stable thereafter. Similar treatment with D-Ala-D-Ala caused a negligible change in fluorescence yield $(+0.9 \%)$ and no shift in the wavelength of maximum emission, confirming the stereochemical specificity of the binding being observed. AlaPhe produced an identical shift in the fluorescence maximum to that seen with AlaAla and a decrease in fluorescence of $11.9 \%$ (Fig. 4b), whereas Ala-D-Phe

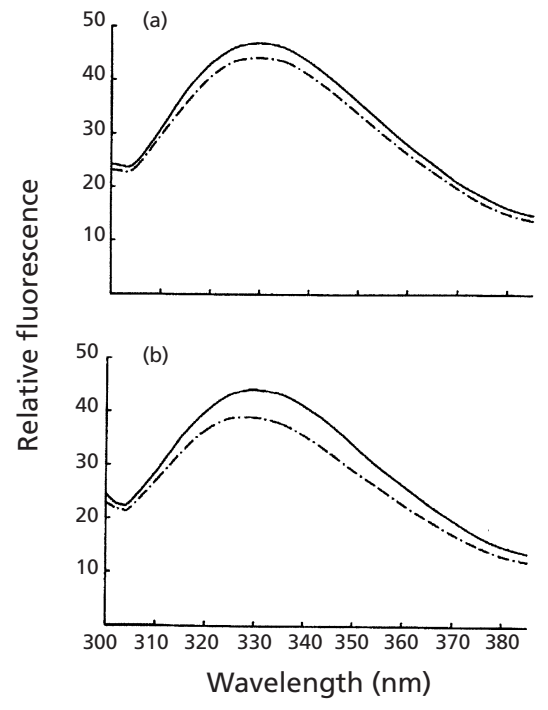

Fig. 4. Fluorescence emission spectroscopy of DppA incubated with (a) AlaAla and (b) AlaPhe; the broken lines show the spectra with added ligand and the continuous lines the controls for DppA alone.

caused no change in fluorescence maximum and a shift of $0.7 \%$ in fluorescence yield (results not shown). Similar experiments were also performed with DppA further purified by RPC: the shifts in wavelength and the decreases in fluorescence emission, observed on addition of the peptides, were of a similar magnitude and relative order as described above (results not shown). Overall, therefore, these observations support the conclusion that DppA undergoes conformational change upon substrate binding and that this binding shows stereochemical specificity, as demonstrated by the IEF assays.

\section{Stoichiometry of peptide binding to DppA}

Samples of DppA, either MonoQ-purified or RPCpurified, were incubated with a range of concentrations of Ala $\left[{ }^{14} \mathrm{C}\right] \mathrm{Phe}$, and the extent of substrate binding was determined using the ammonium-sulphate-assisted filter binding assay (see Methods). The results indicated an approach towards binding saturation in both instances (Fig. 5). However, binding of $\mathrm{Ala}\left[{ }^{14} \mathrm{C}\right]$ Phe was accomplished relatively more easily and more effectively with the RPC sample. Given the inherent errors in estimating the concentrations of both the protein and the peptide in these circumstances, we interpret these results to indicate a $1: 1$ stoichiometry of substrate to protein binding. A Scatchard plot and semi-log plot of these data (results not shown) gave evidence of endogenous bound ligand but overall also endorsed this conclusion of a 1:1 stoichiometry. Similar observations and conclusions were made using $\left[{ }^{14} \mathrm{C}\right] \mathrm{AlaAla}$ (results not shown). The different behaviour seen with the two protein samples in these experiments accords with the differences observed in their IEF profiles, and is compatible with the presence of a fraction of ligand-bound forms in the MonoQ sample, which become ligand-free following RPC. 


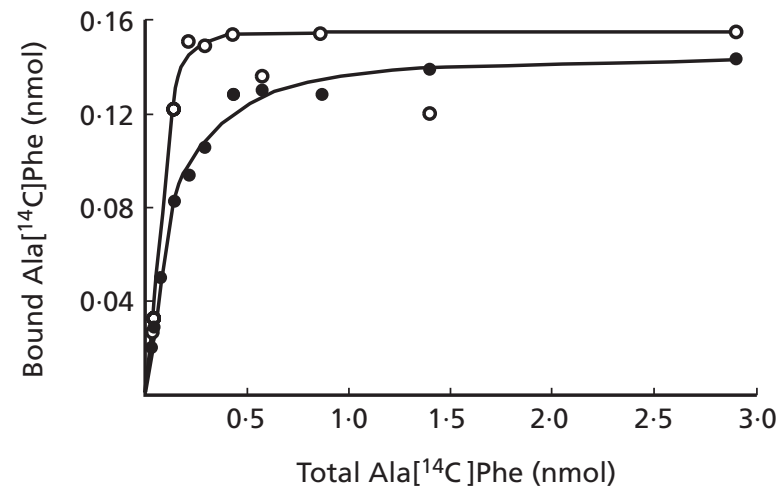

Fig. 5. Filter binding assay of $\mathrm{Ala}\left[{ }^{14} \mathrm{C}\right] \mathrm{Phe}$ to DppA. Protein $(0.18 \mathrm{nmol})$ purified by ion-exchange chromatography (O) or after further RPC (O) was incubated with various concentrations of peptide and the amount of ligand bound was determined by measuring radioactivity after ammonium sulphate precipitation and membrane filtration.

\section{pH dependence of peptide binding to DppA}

Samples of DppA, purified by ion-exchange chromatography, were incubated with Ala $\left[{ }^{14} \mathrm{C}\right] \mathrm{Ala}$ in buffers covering the range $\mathrm{pH} 3-9 \cdot 5$ (see Methods) and peptide binding was determined using the filter binding assay. Under the standard conditions used, binding occurred to the same extent at each $\mathrm{pH}$, being $0 \cdot 15 \pm 0.02 \mathrm{nmol}$ dipeptide over the complete range (results not shown).

\section{Specificity of substrate binding to DppA}

With the availability of pure DppA, and the development of the filter binding assay, it became feasible to measure the binding of various substrates to DppA, and to relate the results to overall transport properties of Dpp. Thus, the binding affinities for a collection of test peptides were determined by measuring their relative abilities to compete for binding with a radioactively labelled peptide standard. However, neither $\left[{ }^{14} \mathrm{C}\right] \mathrm{AlaAla}$ nor Ala $\left[{ }^{14} \mathrm{C}\right]$ Phe proved a convenient standard for this purpose, because they possessed relatively high affinities compared with most other peptide competitors. Consequently, Gly $\left[{ }^{125} \mathrm{I}\right] \mathrm{Tyr}$ was prepared and purified, as a substrate with a lower affinity and with a high specific radioactivity.

\section{Specificity for side chains and peptide length}

The ability of a representative collection of peptides to compete for binding with Gly $\left[{ }^{125} \mathrm{I}\right] \mathrm{Tyr}$ is shown in Table 1. The designation of DppA as a dipeptide-binding protein is substantiated by these results. All tested dipeptides are competitors and they are considerably more effective than tripeptides. However, tripeptides do show some competitive activity, a conclusion in accord with earlier observations that certain tripeptides achieve a low level of accumulation through Dpp (Alves \& Payne, 1980). Thus, both tripeptide uptake activity and competitive binding activity are generally very low, and accordingly the binding of $\left[{ }^{125} \mathrm{I}_{2}\right]$ TyrGlyGly is not
Table 1. Competitive binding to the dipeptide binding protein

Gly $\left[{ }^{125} \mathrm{I}\right]$ Tyr was used as substrate, with peptide competitors used at the indicated molar ratios. Results are the mean of at least duplicate filter binding assays, which deviated by less than $5 \%$.

\begin{tabular}{|c|c|c|c|}
\hline \multirow[t]{2}{*}{$\begin{array}{l}\text { Peptide } \\
\text { competitor }\end{array}$} & \multicolumn{3}{|c|}{$\begin{array}{l}\text { Substrate inhibition }(\%) \\
\text { at indicated } \\
\text { substrate : competitor ratio }\end{array}$} \\
\hline & $1: 0 \cdot 125$ & $1: 1$ & $1: 5$ \\
\hline AlaAla & 72 & 99 & 100 \\
\hline Ala-D-Ala & - & 0 & 35 \\
\hline D-AlaAla & - & 0 & 58 \\
\hline D-Ala-D-Ala & - & 0 & 0 \\
\hline AlaGly & - & 52 & 78 \\
\hline D-AlaGly & - & 0 & 6 \\
\hline AlaGlu & - & 61 & 99 \\
\hline AlaGln & 23 & 44 & 98 \\
\hline AlaAsp & - & 19 & 78 \\
\hline AlaLys & 59 & 83 & - \\
\hline GlyGly & 0 & 0 & 17 \\
\hline GlyLeu & $1 \cdot 1$ & 54 & - \\
\hline Gly-D-Leu & - & 0 & 0 \\
\hline GlyPhe & 53 & 68 & 92 \\
\hline GlyTyr & 22 & 39 & 47 \\
\hline LysAla & 57 & 88 & - \\
\hline GluAla & 7 & 45 & 94 \\
\hline AspAla & - & 17 & 70 \\
\hline AspPhe & 25 & 70 & 93 \\
\hline GluGlu & - & 47 & 92 \\
\hline GlnGln & - & 30 & 99 \\
\hline AspGlu & - & 55 & 85 \\
\hline AspGln & - & 30 & 56 \\
\hline GluLys & - & 40 & 76 \\
\hline AspLys & - & 0 & 7 \\
\hline LeuLeu & - & 25 & 100 \\
\hline Leu-D-Leu & - & 0 & 19 \\
\hline D-LeuLeu & - & 0 & 0 \\
\hline D-Leu-D-Leu & - & 0 & 0 \\
\hline AlaAlaAla & - & 14 & 21 \\
\hline LysAlaAla & - & 10 & 24 \\
\hline
\end{tabular}

measurable (as described above). With dipeptides, a wide range of side chains is acceptable, including small neutral, bulky hydrophobic, and positively and negatively charged groups, although variations in affinity are apparent. With alanyl dipeptides, neutral, anionic and cationic C-terminal residues show little variation in affinity, although a glycine residue is particularly detrimental. GlyGly itself is a very poor competitor, this much reduced affinity corresponding well with its very low uptake rate (Payne \& Bell, 1979; Perry \& Gilvarg, 1984). The relative affinities of AlaAla, LysAla and GluAla accord exactly with their relative affinities for transport reported previously using a spectrophotometric transport assay for dipeptides (Perry \& Gilvarg, 1984). 


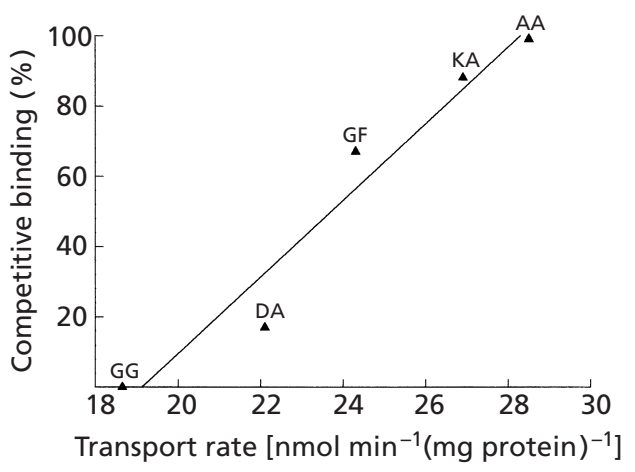

Fig. 6. Plot of percentage competitive binding (taken from Table 1) for various dipeptides against their rates of uptake by Dpp measured in strain PA0410 $\Delta(o p p)$ tpp using the fluorescamine assay. Transport rates were determined from the slope of the line obtained by plotting incubation times, about 10 measurements taken over an incubation period of 10-15 min, against fluorescence yield of peptide remaining in solution after its incubation with fluorescamine. Standard twoletter abbreviations are used for the dipeptides.

Thus, for simple dipeptides, the available literature results upon transport specificities by Dpp are all broadly in agreement with the competitive binding abilities of peptides to DppA found in the filter binding assay (Table 1). However, we studied this conclusion further by performing direct transport measurements using strain PA0410 (opp t $p$ ), which retains only a functional Dpp. For this, we used the fluorescamine assay (see Methods), with a selection of peptides used in the filter binding studies. The results for dipeptide uptake obtained with strain PA0410 (Fig. 6), show a good correlation between transport rates and binding to DppA, again endorsing the primary role of DppA in determining specificity and effectiveness of transport by Dpp.

\section{Stereochemical specificity}

The stereochemical preference for L-residues for dipeptide binding is also apparent from the DppAbinding studies (Table 1). Dipeptides containing one or more D-residues show no, or much diminished, competitive ability. It is possible that the presence of contaminating peptide of L-stereochemistry may be responsible for the limited competitive effect observed (checks for the purity of chirality of these commercial peptides were not performed). Earlier conclusions upon the stereospecificity of dipeptide transport (Payne \& Bell, 1979; Payne 1980; Atherton et al., 1983) are endorsed by these DppA binding studies. Additionally, however, we measured dipeptide transport using fluorescence assays (see Methods) and found that transport was undetectable with the following peptides: LD, DL and DD forms of AlaAla, ValVal and LeuLeu, and D-AlaGly, Gly-D-Ala, D-LeuGly and Gly-D-Leu. Thus, the observed stereospecificity of substrate binding to DppA matches the dipeptide transport specificity.
Table 2. Abilities of substituted dipeptides to compete for binding to the dipeptide-binding protein

Gly $\left[{ }^{125} \mathrm{I}\right] \mathrm{T}$ yr was used as substrate, with peptide competitors used at the indicated molar ratios. Results are the mean of at least duplicate filter binding assays, which deviated by less than $5 \%$.

\begin{tabular}{|c|c|c|c|}
\hline \multirow[t]{2}{*}{ Peptide competitor } & \multicolumn{3}{|c|}{$\begin{array}{c}\text { Substrate inhibition } \\
(\%) \text { at indicated } \\
\text { substrate: competitor } \\
\text { ratio }\end{array}$} \\
\hline & $1: 1$ & $1: 5$ & $1: 50$ \\
\hline AlaAla & 99 & 100 & - \\
\hline $\mathrm{Ala}-\Psi\left(\mathrm{CH}_{2} \mathrm{NH}\right)-\mathrm{Ala}$ & - & $6^{*}$ & - \\
\hline $\mathrm{Ala}-\Psi\left(\mathrm{CH}_{2} \mathrm{NH}\right)-\mathrm{D}-\mathrm{Ala}$ & - & $22 *$ & - \\
\hline $\mathrm{D}-\mathrm{Ala}-\Psi\left(\mathrm{CH}_{2} \mathrm{NH}\right)-\mathrm{Ala}$ & - & $15 \%$ & - \\
\hline D-Ala- $\Psi\left(\mathrm{CH}_{2}^{2} \mathrm{NH}\right)-\mathrm{D}-\mathrm{Ala}$ & - & $10 *$ & - \\
\hline Me-AlaAla & 46 & 76 & - \\
\hline Ac-AlaAla & - & 0 & - \\
\hline AlaGly & 52 & 78 & 99 \\
\hline Bz-AlaGly & - & 0 & 5 \\
\hline GlyGly & 0 & 17 & 42 \\
\hline Me-GlyGly & - & 0 & 39 \\
\hline Et-GlyGly & 0 & 14 & 53 \\
\hline Pr-GlyGly & 3 & 25 & 79 \\
\hline Bu-GlyGly & 0 & 35 & 91 \\
\hline isoPr-GlyGly & - & 33 & 78 \\
\hline isoBu-GlyGly & - & 47 & 77 \\
\hline diMe-GlyGly & 0 & 0 & 0 \\
\hline AspPhe & 70 & 93 & - \\
\hline AspPhe-OMe & 0 & 24 & 50 \\
\hline AlaAla-P† & - & 31 & 64 \\
\hline cyclo-LeuAla & - & 0 & $0 \neq$ \\
\hline cyclo-LeuGly & - & 0 & $0 \neq$ \\
\hline cyclo-ProGly & - & 0 & $0 \neq$ \\
\hline
\end{tabular}

* Substrate to competitor ratio used was $1: 10$.

† Ala-P is L-1-aminoethylphosphonic acid.

$\ddagger$ Substrate to competitor ratio used was $1: 100$.

\section{Effects of modifications to peptide structure}

The effects of modifications to dipeptide structure upon substrate affinity for DppA were also measured for a variety of peptidomimetics (Table 2). Reduction of the peptide bond, as in Ala- $\Psi\left(\mathrm{CH}_{2} \mathrm{NH}\right)$ Ala, still permitted low-level binding; interestingly, peptides containing $\mathrm{D}-$ residues showed activities more comparable with Lstereoisomeric forms than is seen normally with natural peptides. 5-Aminolaevulinic acid is an analogue of GlyGly in which the peptide bond has also been modified; it possessed very low competitive ability, with percentage inhibitions of $0,6,8,25,36$ and $52 \%$ at competitor to substrate ratios of $10,50,100,250,500$ and 600 to 1 , respectively. In accord with these results, 5aminolaevulinic acid has been shown to be a specific but poor substrate for Dpp in E. coli and S. typhimurium 
(Abouhamad et al., 1991; Abouhamad \& Manson, 1994; Elliot, 1993; Verkamp et al., 1993). Alkylation of the N-terminal amino group, as with Me-AlaAla and the glycyl peptide series, is well tolerated, a result in accord with earlier transport studies (Payne, 1974; Atherton et al., 1983). However, the present binding studies indicate that enhanced competitiveness occurs with increasing size/hydrophobicity of the alkyl group, (butyl > propyl $>$ ethyl $>$ methyl); this progressive increase in affinity was not detectable in earlier transport studies (Payne, 1974). Complete removal of the positive charge from the N-terminal $\alpha$-amino group, as with the dimethyl-, acetyl- and benzoyl-derivatives (Table 2), abolished binding, a feature noted previously for dipeptide transport (Payne, 1974; Payne \& Smith, 1994). Modifications to the C-terminal $\alpha$-carboxyl group had a marked inhibitory effect on binding affinity (Table 2), although a low level of binding was still detectable. This conclusion accords with earlier results on dipeptide uptake (Payne, 1980; Atherton et al., 1983). Cyclization of a dipeptide through its $\mathrm{N}$ - and C-termini, to form the corresponding diketopiperazines, abolished binding (Table 2).

Overall, these results on substrate specificity are in accord with the insights that have been provided by the crystal structure studies with DppA and OppA (Dunten \& Mowbray, 1995; Nickitenko et al., 1995;Tame et al., 1994, 1995), in which the mechanisms involved in stabilizing protein interactions with the $\mathrm{N}$ - and Ctermini, backbone atoms and side-chain residues of the substrates have been clarified.

\section{DISCUSSION}

The results presented here provide extensive information on the substrate specificities of the dipeptidebinding protein (DppA) component of the dipeptide permease (Dpp) of E. coli. Hitherto, no systematic or extended study has been carried out on the transport specificities of Dpp, and the limited results available have largely been obtained from indirect transport studies using strains that were not always well characterized with respect to their complement of peptide permeases (Payne \& Smith, 1994). Furthermore, no binding studies to DppA with dipeptides and analogues have previously been reported. An initial objective of the present studies was to relate the transport rates of various substrates by Dpp to their affinities for DppA. It is well recognized that a binding protein performs the essential first step in the recognition and binding of substrates of traffic ATPases such as Dpp (Ames et al., 1990), However, it is uncertain for a protein such as DppA, which has a vast array of potential substrates, whether its binding specificity alone determines overall transport rates, or whether the Dpp membrane-bound proteins involved in the translocation step might interact with the substrates in a way that could affect overall transport.

To explore this, three aims needed to be met: firstly, it was necessary to obtain pure DppA free from en- dogenous ligand; secondly, to obtain strains in which one or more of the main peptide transporters of E. coli were inactivated so that transport measurements could be related strictly to one or other transporter; and, finally, assays for binding to DppA needed to be developed.

With regard to the first aim, we describe a suitable purification scheme for DppA, together with the novel application of RPC to produce ligand-free protein. In subsequent studies (results not shown), we have found that ligand removal can conveniently be achieved using a batch procedure, in which ion-exchange-purified DppA was redissolved in aqueous TFA $(0 \cdot 1 \%, w / v)$ containing acetonitrile $(50 \%, \mathrm{v} / \mathrm{v})$, and then dialysed against solutions in which the TFA and acetonitrile concentrations were decreased progressively in three steps; this procedure proved to be more effective at removing tightly bound endogenous ligands than simply dialysing against buffer solutions. In addition, we have found it advantageous to use E. coli strain JM101, which overproduces DppA when grown in minimal medium (Olson et al., 1991).

Regarding the second objective, we have described the selection and use of mutants defective in the three main peptide transporters. Selection and use of strains PA0333 $(o p p d p p)$ and PA0410 (opp tpp) is described here. In further studies (results not shown) we derived strains deficient in all three peptide transport systems $(o p p d p p$ $t p p)$ : starting from strain PA0333 (opp $d p p$ ) a $t p p$ mutant, strain PA0643 (opp $d p p t p p$ ) was selected using resistance to alafosfalin, coupled with cross-resistance to ValGly and failure to grow on LeuTrp; and from strain PA0410 (opptpp) a $d p p$ mutant, PA0610 (opp $d p p$ $t p p)$, was selected using resistance to valclavam and cross-resistance to ProVal. These triple mutant strains showed complete resistance to toxic peptides and failed to grow on any simple peptides containing Leu or Trp as sources of their auxotrophic requirements; they are effectively unable to transport di-, tri- and oligopeptides. Using complementation analysis with episomes in strains PA0643 and PA0410, we showed that $t p p$ maps to a gene at $36 \mathrm{~min}$ (p77304 in the SWISS-PROT database), homologous to the proton-motive-force-driven peptide transporter in lactobacilli (Nakajima et al., 1997) and containing the Ptr motif, indicating that its energy coupling is by $\mathrm{H}^{+}$rather than ATP (Steiner et al., 1995). This confirms that Tpp lacks a binding protein, in agreement with earlier suggestions that it is not an $\mathrm{ABC}$ transporter (Smith, 1992; Payne \& Smith, 1994) and with the finding here that in the osmotic shock fluid the only protein able to bind the radioactively labelled dipeptide was DppA.

To meet the third aim, we have developed several complementary assays: one based on radioactively labelled ligand-DppA complexes precipitated by ammonium sulphate onto membrane filters (Figs 2 and 5 ; Tables 1 and 2), and another using IEF to measure the mobility shifts that occur when DppA binds ligands (Fig. 3). 
The first assay requires a peptide substrate of high specific activity but relatively poor affinity; peptides containing iodinated tyrosine best satisfy the first requirement and should ideally be linked to glycyl or proline residues, which give the lowest affinities and poorest transport. Thus, Gly $\left[{ }^{125} \mathrm{I}\right] \mathrm{Tyr}$ is an optimal choice, and this substrate allowed relative binding affinities to be obtained for a range of natural and substituted peptides. However, the absence of competitive ability of certain peptides, e.g. GlyGly, in this assay simply means that in the equilibrium binding conditions with Gly $\left[{ }^{125} \mathrm{I}\right] \mathrm{Tyr}$ they are very poor competitors; it does not imply that GlyGly cannot be transported (Fig. 6), simply that it is transported relatively poorly compared with Gly $\left[{ }^{125} \mathrm{I}\right] \mathrm{Tyr}$. The second assay allows measurement of the relative abilities of different peptides to bind to DppA by incubating the protein with different amounts of substrate and seeing how much is needed to effect a mobility shift. A secondary observation to emerge from these studies is that different peptides can give rise to ligand complexes with different isoelectric points. This is not simply a function of charge on the peptide, because uncharged peptides, e.g. AlaAla and AlaPhe, also produce shifts, and they are different from each other. We interpret these varied $\mathrm{pI}$ forms as indicating that the protein can adopt several different conformations, caused by substrates being bound slightly differently. However, it is possible that different ligands cause varied ionization of binding-site residues and that this alone may be responsible for the varied $\mathrm{pI}$ forms.

It follows from these studies that the ability of any compound to be transported by Dpp can be assessed quantitatively from assays in vitro on substrate binding to pure DppA, rather than by transport measurements per se. This finding facilitates the task of obtaining quantitative structure-activity data for transportable substrates of Dpp, not least because measurements of peptide transport are particularly susceptible to error when using radioactively labelled peptides, as a result of their rapid intracellular cleavage and the concomitant efflux of labelled amino acids (Payne \& Nisbet, 1980).

The results obtained all support the idea that DppA is solely responsible for determining the overall transport parameters for Dpp. Thus, the results available in the literature on the general structural requirements for transport by Dpp match the specificities for binding to DppA found here (Tables 1 and 2). In addition, transport rates by Dpp measured in strain PA0410 (Fig. 6), in which Opp and Tpp are non-functional, parallel the results found for the relative binding to DppA for simple dipeptides and various stereoisomeric forms.

The structure-activity results described here provide a useful resource to explore the fundamental basis of molecular recognition by DppA, which can also be applied in the rational design of antimicrobial peptidomimetics able to be transported by Dpp (Payne, 1995 ; Tyreman et al., 1992, 1998). In recent work (J. W. Payne, B. M. Grail \& N. J. Marshall, unpublished), we have carried out computer-based conformational analy- ses of many of the peptides used in these studies. This work has revealed the structural principles that determine the relative affinities of natural peptides for DppA, thrown light on the reason for the occurrence of varied $\mathrm{pI}$ forms of the liganded protein, and provided insight into the selective pressures operating in the evolution of natural smugglins, making it possible for the first time to design optimal structures for delivering antimicrobial compounds to their intracellular targets by exploiting peptide transporters.

\section{ACKNOWLEDGEMENTS}

We thank Barry Grail and Huw Jones for their invaluable help with certain aspects of the studies described here, and the BBSRC for financial support.

\section{REFERENCES}

Abouhamad, W. N. \& Manson, M. D. (1994). The dipeptide permease of Escherichia coli closely resembles other bacterial transport systems and shows growth-phase-dependent expression. Mol Microbiol 14, 1077-1092.

Abouhamad, W. N., Manson, M., Gibson, M. M. \& Higgins, C. F. (1991). Peptide transport and chemotaxis in Escherichia coli and Salmonella typhimurium: characterization of the dipeptide permease (Dpp) and the dipeptide-binding protein. Mol Microbiol 5, 1035-1047.

Alves, R. A. \& Payne, J. W. (1980). The number and nature of the peptide transport systems of $E$. coli: characterization of specific transport mutants. Biochem Soc Trans 8, 704-705.

Ames, G. F.-L., Mimura, C. S. \& Shyamala, V. (1990). Bacterial periplasmic permeases belong to a family of transport proteins operating from E. coli to humans: traffic ATPases. FEMS Microbiol Rev 75, 429-446.

Atherton, F. R., Hall, M. J., Hassall, C. H., Lambert, R. W., Lloyd, W. J., Lord, A. V., Ringrose, P. S. \& Westmacott, D. (1983). Phosphonopeptides as substrates for peptide transport systems and peptidases of Escherichia coli. Antimicrob Agents Chemother 24, 522-528.

Berger, E. A. \& Heppel, L. A. (1972). A binding protein involved in the transport of cystine and diaminopimelic acid in Escherichia coli. J Biol Chem 274, 7684-7694.

Blank, V. (1987). Dipeptidchemotaxis in Escherichia coli: Beteiligung des Tap-signaltransducers und des Dpp-transportsystems. Diploma thesis, University of Konstanz, Germany.

Davis, B. D. \& Mingioli, E. S. (1950). Mutants of Escherichia coli requiring methionine or vitamin $\mathrm{B}_{12}$.J Bacteriol 60, 17-28.

Dunten, P. \& Mowbray, S. L. (1995). Crystal structure of dipeptide binding protein from Escherichia coli involved in active transport and chemotaxis. Protein Sci 4, 2327-2334.

Elliot, T. (1993). Transport of 5-aminolevulinic acid by the dipeptide permease in Salmonella typhimurium. J Bacteriol 175, 325-331.

Gibson, M. M., Price, M. \& Higgins, C. F. (1984). Genetic characterization and molecular cloning of the tripeptide permease (Tpp) genes of Salmonella typhimurium. J Bacteriol 160, 122-130.

Goodell, E. W. \& Higgins, C. F. (1987). Uptake of cell wall peptides by Salmonella typhimurium and Escherichia coli. J Bacteriol 169, 3861-3865.

Grimble, G. K. \& Backwell, F. R. C. (editors) (1998). Peptides in Mammalian Protein Metabolism: Tissue Utilization and Clinical Targeting. London \& Miami: Portland Press. 
Guyer, C. A., Morgan, D. G. \& Staros, J. V. (1986). Binding specificity of the periplasmic oligopeptide-binding protein from Escherichia coli. J Bacteriol 168, 775-779.

Hammond, S. M., Claesson, A., Jansson, A. M., Larsson, L. G., Pring, B. G., Town, C. M. \& Ekstrom, B. (1987). A new class of synthetic antibacterials acting on lipopolysaccharide biosynthesis. Nature 327, 730-732.

Heukeshoven, J. \& Dernick, R. (1988). Improved silver staining procedure for fast staining in Phastsystem development unit. Electrophoresis 9, 28-32.

Hiles, I. D., Gallagher, M. P., Jamieson, D. J. \& Higgins, C. F. (1987). Molecular characterization of the oligopeptide permease of Salmonella typhimurium. J Mol Biol 195, 125-142.

Igarashi, K., Hiraga, S \& Yura, T. (1967). A deoxythymidine kinase deficient mutant of E. coli mapping and transduction studies with phage $\phi 80$. Genetics 57, 643-654.

Laemmli, U. K. (1970). Cleavage of structural proteins during the assembly of the head of bacteriophage T4. Nature 227, 680-685.

Manson, M. D., Blank, V., Brade, G. \& Higgins, C. F. (1986). Peptide chemotaxis in E. coli involves the Tap signal transducer and the dipeptide permease. Nature 321, 253-256.

Matthews, D. M. \& Payne, J. W. (1980). Transmembrane transport of small peptides. Curr Top Membr Transp 14, 331-425.

Morley, J. S., Payne, J. W. \& Hennessey, T. D. (1983). Antibacterial activity and uptake into Escherichia coli of backbone-modified analogues of small peptides. J Gen Microbiol 129, 3701-3708.

Morse, D. E. \& Guertin, M. (1972). Amber suA mutations which relieve polarity. J Mol Biol 63, 605-608.

Nakajima, H., Hagting, A., Kunji, E. R. S., Poolman, B. \& Konings, W. N. (1997). Cloning and functional expression in Escherichia coli of the gene encoding the di- and tripeptide transport protein of Lactobacillus helviticus. Appl Environ Microbiol 63, 22132217.

Nickitenko, A. V., Trakhanov, S. \& Quiocho, F. A. (1995). $2 \AA$ resolution structure of DppA, a periplasmic dipeptide transport/ chemosensory receptor. Biochemistry 34, 16585-16595.

Olson, E. R., Dunyak, D. S., Jurss, L. M. \& Poorman, R. A. (1991). Identification and characterisation of $d p p A$, an E. coli gene encoding a periplasmic dipeptide transport protein. J Bacteriol 173, 234-244.

Park, J. T., Debabrata, R., Li, H., Normark, S. \& Mengin-Lecreulx, D. (1998). MppA, a periplasmic binding protein essential for import of the bacterial cell wall peptide L-alanyl- $\gamma$-D-glutamylmeso-diaminopimelate. J Bacteriol 180, 1215-1223.

Payne, J.W. (1974). Peptide transport in Escherichia coli: permease specificity towards terminal amino group substituents. J Gen Microbiol 80, 269-276.

Payne, J. W. (1980). Transport and utilization of peptides by bacteria. In Microorganisms and Nitrogen Sources, pp. 211-256. Edited by J. W. Payne. Chichester \& London: Wiley.

Payne, J. W. (1986). Drug delivery systems: optimising the structure of peptide carriers for synthetic antimicrobial drugs. Drugs Exp Clin Res 12, 585-595.

Payne, J. W. (1995). Bacterial peptide permeases as a drug delivery target. In Peptide Based Drug Design: Controlling Transport and Metabolism, pp. 341-367. Edited by M. D. Taylor \& G. L. Amidon. Washington, DC: ACS Books.

Payne, J. W. \& Bell, G. (1979). Direct determination of the properties of peptide transport systems in Escherichia coli, using a fluorescent-labelling procedure. J Bacteriol 137, 447-455.

Payne, J. W. \& Gilvarg, C. (1968). Role of the terminal carboxyl group in peptide transport in Escherichia coli. J Biol Chem 243, 335-340.

Payne, J. W. \& Nisbet, T. M. (1980). Limitations to the use of radioactively-labelled substrates for studying peptide transport in microorganisms. FEBS Lett 119, 73-76.

Payne, J. W. \& Smith, M. W. (1994). Peptide transport by microorganisms. Adv Microb Physiol 36, 1-80.

Payne, J. W., Morley, J. S., Armitage, P. \& Payne, G. M. (1984). Transport and hydrolysis of antibacterial peptide analogues in Escherichia coli: backbone-modified aminoxy peptides. J Gen Microbiol 130, 2253-2265.

Perry, D. \& Gilvarg, C. (1984). Spectrophotometric determination of affinities of peptides for their transport systems in Escherichia coli. J Bacteriol 160, 943-948.

Pugsley, A. P. \& Reeves, P. (1976). Iron uptake in colicin B resistant mutants of Escherichia coli K12. J Bacteriol 126, 1052-1062.

Richarme, G. \& Kepes, A. (1983). Study of binding protein-ligand interaction by ammonium sulphate-assisted adsorption on cellulose ester filters. Biochim Biophys Acta 742, 16-24.

Smith, M. W. (1992). Characterization and exploitation of microbial peptide transport systems. $\mathrm{PhD}$ thesis, University of Wales, Bangor.

Smith, M. W. \& Payne, J. W. (1990). Simultaneous exploitation of different peptide permeases by combinations of synthetic peptide smugglins can lead to enhanced antibacterial activity. FEMS Microbiol Lett 70, 311-316.

Steiner, H. Y., Naider, F. \& Becker, J. M. (1995). The PTR family a new group of peptide transporters. Mol Microbiol 16, 825-834.

Tame, J. R. H., Murshudov, G. N., Dodson, E. J., Neil, T. K., Dodson, G. G., Higgins, C. F. \& Wilkinson, A. J. (1994). The structural basis of sequence-independent peptide binding by OppA protein. Science 264, 1578-1581.

Tame, J. R. H., Dodson, E. J., Marshudov, G., Higgins, C. F. \& Wilkinson, A. J. (1995). The crystal structures of the oligopeptidebinding protein OppA complexed with tripeptide and tetrapeptide ligands. Structure 3, 1395-1406.

Taylor, M. D. \& Amidon, G. L. (editors) (1995). Peptide-based Drug Design: Controlling Transport and Metabolism. Washington, DC: American Chemical Society.

Tyreman, D. R., Smith, M. W., Payne, G. M. \& Payne, J. W. (1992). Exploitation of peptide transport systems in the design of antimicrobial agents. In Molecular Aspects of Chemotherapy, pp. 127-142. Edited by D. Shugar, W. Rode \& E. Borowski. Berlin: Springer.

Tyreman, D. R., Smith, M. W., Marshall, N. J., Payne, G. M., Schuster, C. F., Grail, B. M. \& Payne, J. W. (1998). Peptides as prodrugs: the smugglin concept. In Peptides in Mammalian Protein Metabolism: Tissue Utilisation and Clinical Targeting, pp. 141-157. Edited by G. K. Grimble \& F. R. C. Backwell. London: Portland Press.

Verkamp, E., Bachman, V. M., Bjornsson, J. M., Soll, D. \& Eggertsson, G. (1993). The periplasmic dipeptide permease system transports 5-aminolevulinic acid in Escherichia coli. J Bacteriol 175, 1452-1456.

Received 16 April 1999; revised 17 June 1999; accepted 24 June 1999. 